\title{
Microbiota and Mycotoxins in Trilinear Hybrid Maize Produced in Natural Environments at Central Region in Mexico
}

\author{
Peña Betancourt, Silvia Denise \\ Toxicology Laboratory, Department of Agricultural and Animal Production, Autonomous Metropolitan \\ University, Unit-Xochimilco, Mexico City, Mexico \\ Email: s.denisepena@gmail.com
}

Received 18 June 2016; accepted 8 August 2016; published 11 August 2016

Copyright @ 2016 by authors and Scientific Research Publishing Inc.

This work is licensed under the Creative Commons Attribution International License (CC BY). http://creativecommons.org/licenses/by/4.0/

(c) (i) 0pen Access

\begin{abstract}
Mycotoxigenic fungi and mycotoxins in 3 inbred lines (hybrids resistant to corn ear rot) were identified in twenty samples. The maize (Zea mays) accessions were collected in five plots of two municipalities in High Valley, state of Hidalgo. The fungal population was determined with a microbiological dilution method used two culture media (PDA and ELA), for the detection of mycotoxins with thin layer chromatography with visual inspection in UV light and a direct competitive enzyme-linked immunosorbent (ELISA). The results showed high moisture content in all hybrids evaluated on an average of $38.3 \%$ and a $1.8 \times 10^{3} \mathrm{UFC} / \mathrm{g}$ fungus, values within the permitted limits by the Mexican legislation; however the most prevalent fungi were Fusarium sp. (76\%), Alternaria sp. (14\%), Penicillium sp. (4\%) and Aspergillus sp. (5\%), and the species Aspergillus nidulas, Aspergillus flavus, Fusarium verticillioides, Fusarium poae, and Penicillium ochraceum. The aflatoxin concentration was observed in a range from 2 to $13 \mathrm{ng} / \mathrm{g}$ and 370 to $660 \mathrm{ng} / \mathrm{g}$ to fumonisins. It is concluded that trilinear corn hybrids have a variety of pathogenic potential fungi. The two genetic hybrids showed levels of aflatoxins and fumonisin safe for human consumption, contrary to one hybrid, with a content not suitable for human consumption. A better understanding of genetic hybrids corn will improve predictive mycotoxin contamination.
\end{abstract}

\section{Keywords}

Zea mays L., Mycotoxins, Fungi, Corn Hybrid

\section{Introduction}

In Mexico, 19.7 million tons of corn annually occurs in an area of 7.4 million hectares, with enormous variations

How to cite this paper: Betancourt, P. and Denise, S. (2016) Microbiota and Mycotoxins in Trilinear Hybrid Maize Produced in Natural Environments at Central Region in Mexico. Advances in Microbiology, 6, 671-676.

http://dx.doi.org/10.4236/aim.2016.69066 
in production from one year to another [1], principally due to the attacks by fungus that can cause losses of up to $20 \%$ in harvest [2] [3]. The introduction of hybrid maize comes from three pure lines, with a resistance to fungus, which had improved productivity in some maize growing areas [4] [5]. In 2006, the central region from Hidalgo State, had losses in corn harvest, when appearing on their land plants falls, cobs smaller grain discolored dark and leaves with the presence of a pink powder.

Insects have been related to the transport of pathogenic fungi Aspergillus sp., Fusarium sp. and Penicillium sp. [6]; among them, the Hymenoptera, Lepidoptera and Diptera; the most frequently funding in corn plant [6] [7]. Another factor that directly influences the development of fungi and mycotoxins is the weather, as intense rains during seed germination. Fungus uses their spores to reach the grain, causing physical and ear rot [8] deterioration and a high temperature can cause a decrease in grain yield per hectare [9]. The combined effect of oxygen and moisture environment promotes the synthesis of mycotoxins, which once installed cannot be deleted [10]; these mycotoxins constitute a risk to human and animal health [3]. The fungus Aspergillus flavus synthesizes aflatoxins [11]; they can cause hepatotoxicity in poultry, swine, cattle, sheep and laboratory animals, making morphological changes in liver cells as the change in the nucleolus, derangement and reduction in the number of ribosomes, proliferation of smooth endoplasmic reticulum and mitochondria degeneration and a decrease in protein synthesis; the toxicity is associated with low food intake, poor growth, low production, reduced fertility and immunosuppression. Fusarium verticillioides and Fusarium oxysporum have the same toxigenic effect as the fusariotoxin F-2, a mycotoxin with diverse estrogenic activity; in pigs, females and males, had shown an increase in the size of the mammary glands, include the human beings. Fusarium verticillioides synthesizes fumonisin, which has been involved with the development of esophageal cancer in humans [12] [13]. Penicillium sp. represents a large number of species of filamentous fungi, identified at least 300 species; Penicillium ochraceus produces Ochratoxin A, whose toxicity is associated with the isocumarine ring molecule that affects the kidney [14]; Alternaria sp. is an ubiquitous and saprophytic fungus, and Alternaria sp. synthesizes mycotoxins, called alternariol and alterotoxines, whose toxicity has not been sufficiently investigated in Mexico.

Toxic effects of mycotoxins on human health have been known since middle ages, recorded diseases in farm workers after harvest rye; intense documentation has been developed since then, the toxicity of mycotoxins has been intensively in target organs such as liver and lung, as well as the immune and nervous system [15].

Conventional techniques as microbiological isolation in raw and processed foods are still used, although the technique of polymerase chain reaction (PCR) currently identifies pathogens in less time [16]. The official mycotoxin monitoring technique is the thin layer chromatography (TLC). In some laboratories liquid chromatography coupled to mass spectroscopy-mass HPLC/MS/MS is used [17]. One of the quality concepts of maize seed is the germinating vigour, factors involved genetic constitution, maturity at harvest and pathogens [18]. Polyphenolic compounds commonly known as tannins, have been attributed natural insecticidal properties. Therefore the objective of this study was to isolate and identify the microbiota and mycotoxins in corn hybrids and probed the proprieties of hybrid maize.

\section{Materials and Methods}

The study was conducted during the spring-summer crop season, in the municipalities of Tlaxcoapan and Tlahuelilpan, located in the high valley at an altitude of 2,080 $\mathrm{m}$, characterized by a temperate climate with summer rains. In the municipality of Tlaxcoapan threes locations, were sampled under a stratified system. In the municipality of Tlahuelilpan two locations with the same technique in cobs. The agronomic characteristics of corn hybrids are presented in Table 1. Tlaxcoapan: located at $20^{\circ} 05^{\prime} 43^{\prime \prime} \mathrm{N}$ coordinates $99^{\circ} 13^{\prime} 12^{\prime \prime} \mathrm{S}$, at a height of 2,063 $\mathrm{m}$. with a climate $\mathrm{Cw}$, an average temperature of $17^{\circ} \mathrm{C}$ and a rainfall of $850 \mathrm{~mm}$ per year; Tlahuelilpan is located in the coordinates $20^{\circ} 07^{\prime} 47^{\prime \prime} \mathrm{N} 99^{\circ} 13^{\prime} 43^{\prime \prime} \mathrm{S}$, at a height of 2,067 $\mathrm{m}$ with the same climate, an average temperature of $12^{\circ} \mathrm{C}$ and a rainfall of $620 \mathrm{~mm}$ per year. The cobs, were transported to the laboratory of toxicology where it was manually removed the grain, identified and stored.

Laboratory tests: moisture content was determined following the 44 - 40 method [18]; grains were dried at a temperature of $50^{\circ} \mathrm{C}$ for $48 \mathrm{~h}$.

For the total count of microorganisms, it were used randomly 100 grains of each commercial sample hybrid maize, disinfected with sodium hypochlorite $(\mathrm{NaOCl} 2 \%)$ and 20 grains were sown in Petri dish on a medium surface malt agar (MA), malt-salt agar (MSA) and Potato-dextrose-agar (PDA), and were incubated for 7 days at $25^{\circ} \mathrm{C}$. Colonies were counted and expressed as UFC/g. The identification of colonies after staining was per- 
formed with Lactophenol blue light microscopy, based on the macroscopic and microscopic structures of each colony, [11] [19] microbiological density of each hybrid maize was expressed in colony forming units (CFU/g).

It was used thin layer chromatography under UV light by visual comparison to standards, for the screening analysis of aflatoxins and for fumonisins a commercial immunosorbent assay (ELISA). $500 \mathrm{~g}$ of each sample in duplicate were weighed and ground in electric mill, $50 \mathrm{~g}$ of ground corn was weighed and placed in a glass blender $500 \mathrm{~mL}$ with $5 \mathrm{~g}$ of $\mathrm{NaCl}$; it were added $100 \mathrm{~mL}$ of methanol mixture and distilled water 80:20 (v/v) and mixed at high speed for 3 minutes. The extract was passed through a whatman No. 4 and it was collected $25 \mathrm{~mL}$. Extract purification was performed under a C-18 column, eluting aflatoxins with $6 \mathrm{~mL}$ of chloroform and acetone at a ratio of 9:1 v/v. $50 \mu \mathrm{L}$ of the purified extract and applied on silica gel plates 60 (Merck) reversed phase C-18 $1 \mathrm{~cm}$ away, to be introduced into a development chamber $10 \times 10 \mathrm{~cm}$, in a solvent system to acetone and toluene base $(1: 1 \mathrm{v} / \mathrm{v})$. The plates were exposed to ultraviolet light at a short wavelength $(250 \mathrm{~nm})$. Samples with a blue color and a distance equal to 0.50 indicated the presence of aflatoxin $\mathrm{B}$ type, having the same blue color and the front distance standards aflatoxin $\mathrm{B}_{1}$ and $\mathrm{B}_{2}$, and for fumonisin analyse a direct competitive enzymelinked immunosorbent assay (ELISA) and the procedure provided by the manufacturer. $5 \mathrm{~g}$ of each sample were weighed and ground, a methanolic extraction was performed, an aliquot of $50 \mu \mathrm{L}$ in each well of the microplate. A positive reaction is blue color. Finally the test was read to yield optical densities, and it was built a standard curve with controls and samples, to calculate the concentration of fumonisins.

\section{Results}

The contamination by microorganisms in maize hybrids is presented in Table 2, where it can be observed a high level of pollution in the commercial hybrid oso, with a total count of $2.5 \times 10^{3} \mathrm{CFU} / \mathrm{g}$, followed by hybrid leopardo with $1.270 \times 10^{3} \mathrm{CFU} / \mathrm{g}$, and hybrid 30V46 with $1.260 \times 10^{3} \mathrm{CFU} / \mathrm{g}$. The identified fungus were Fusarium sp. and Penicillium sp. in the three varieties of hybrid maize; Alternaria sp. only hybrid maize oso. The species identified were Ocraceus penicillium, Alternaria sp., Aspergillus flavus, Fusarium verticillioides, F. oxysporum and Fusarium moniliforme.

Table 1. Agronomic characteristics of corn hybrids collected in the Mezquital Valley, State of Hidalgo, Mexico.

\begin{tabular}{cccc} 
Genetic corn & Commercial identification & Genetics & Maturity \\
\hline Hybrid & Oso & Three lines & Intermediate-early \\
Hybrid & Leopardo & Three lines & Early \\
Hybrid & 30 V46 & Three lines & Intermediate \\
\hline
\end{tabular}

Table 2. Microbiota of commercial hybrid varieties of maize from the 2007-2008 harvest, Mezquital Valley, Hidalgo State.

\begin{tabular}{|cccc}
\hline Commercial hybrid & Oso & Leopardo & 30 V46 \\
\hline Municipality & Tlaxcoapan & Tlaxcoapan & Tlahuelilpan \\
\hline Total microbiota $^{*}$ & 2.5 & 1.3 & 1.2 \\
Fusarium sp. & 1.4 & 0.99 & 0.89 \\
Penicillium sp. & 4.0 & 5.0 & 1.0 \\
Alternaria sp. & 14 & $\mathrm{NF}$ & $\mathrm{NF}$ \\
Fusarium oxysporum & 38 & $\mathrm{NF}$ & $\mathrm{NF}$ \\
Aspergillus sp. & 10 & $\mathrm{NF}$ & $\mathrm{NF}$ \\
\hline Fusarium moniliforme & 3 & 5 & 5 \\
\hline
\end{tabular}

$\mathrm{NF}=$ not found. 
In Table 3. Observed colony forming units in two culture media (potato dextrose agar and yeast extract agar) of samples taken from the grains and leaves before harvest and grain in the cellar.

In order to assess the percentage of fermentation of the varieties bear and leopard, germination test was performed, which is shown in Table 4. The leopardo variety had a higher germination percentage and higher average height germinated.

The presence and level of fumonisins, mycotoxins, tannic acid detected in corn hybrids is presented in Table 5, which shows that the hybrid leopardo had the most fumonisin contamination compared to the hybrid oso aflatoxin. The corn hybrid 30V46 was the least contamined, and tannin content with large variations between 1.4 $\mathrm{mg} / \mathrm{mL}$ a $3.39 \mathrm{mg} / \mathrm{mL}$.

\section{Discussion}

The high content of colony forming units detected in the commercial hybrid corn oso $2.5 \times 10^{3}$, indicates the susceptibility of genotype, which could be favored by excessive rain that occurred in the two locations in Tlaxcoapan, during the agricultural cycle. It should be noted that fungal colonies were identified in grains of corn hybrids, such as Fusarium species, Alternaria and Aspergillus, in agree with other authors. In this study it were identified Fusarium verticillioides, F. oxysporum, Alternaria and Aspergillus flavus, potentially produced fumonisins, aflatoxins and alternariol, highly dangerous chemicals to human and animal health [5]. Climate change affects all the agricultural field, the many pests that attack the corn plant or dryness, requires producers to care for and ideally manage their crop to achieve an economically and sustainable agricultural production in order to reduce the environmental impact of this activity [20]. The count of colony forming units (for bacteria and yeast) it was found within the national legislation, however is not desirable because the grain remain in storage for long periods sometimes. It is important to know the potential health risk [21]. The hybrid oso was less susceptible to fumonisin than aflatoxins. The 30V46 hybrid remained at low levels for both mycotoxins [22], being the less

Table 3. Colony forming units observed in two culture media (potato dextrose agar and yeast extract agar) of samples taken from the grains and leaves before harvest and grain post-harvest.

\begin{tabular}{ccccc}
\hline \multirow{2}{*}{ Corn } & \multicolumn{2}{c}{ Pre-harvest grain } & \multicolumn{3}{c}{ Grain store } \\
\cline { 2 - 5 } & PDA & ELA & PDA & ELA \\
Oso & 987 & 995 & 1006 & 1026 \\
Leopardo & 635 & 854 & 987 & 995 \\
30V46 & 1006 & 1026 & 635 & 854 \\
Total & 2628 & 2875 & 2628 & 2875 \\
\hline
\end{tabular}

Table 4. Percentage of germination and size for three trilinear hybrid.

\begin{tabular}{ccc}
\hline Genetic line & Seeds & Germination \% \\
\hline 30V46 & 100 & 64 \\
Oso & 100 & 76 \\
Leopard & 100 & 87 \\
\hline
\end{tabular}

Table 5. Identification and quantification of aflatoxin, fumonisin and tannins in improved maize.

\begin{tabular}{ccccc}
\hline Corn & DM (\%) & Fumonisins content (ng/g) & Aflatoxins content (ng/g) & Tannic acid $^{*}(\mathrm{mg} / \mathrm{mL})$ \\
\hline 30V46 & 85.99 & 370 & 2.0 & 3.38 \\
Oso & 85.74 & 250 & 13.0 & 1.40 \\
Leopardo & 86.00 & 660 & 7.5 & 3.40 \\
\hline
\end{tabular}

$\mathrm{DM}=$ dry matter, ${ }^{*}$ Millequivalents of tannic acid. 
contaminated under the conditions of this study, it is important to consider the presence of any other metabolites in plants, such as tannins because they have qualities that can reach inhibit the growth of certain harmful microorganisms to the ground, men and animals [23].

\section{Conclusions}

The presence of fungus and mycotoxins in trilinear hybrids in maize showed a potential risk for human health.

This study showed that mycotoxin contamination depends not only from the genetic seed but also from several factors like the competition into microbiota and weather of each region.

It is important to choose a sensitive method for screening test, and establish the permitted levels of fumonisins in maize and derivatives in Mexico.

\section{References}

[1] SIAP (2007) Servicio de Información Agroalimentaria y Pesquera (SIAP). Con información de las delegaciones de la SAGARPA en los estados. Año agrícola 2007.

[2] Gaytán, B.R., Martínez, G.M. and Mayek, P.N. (2009) Rendimiento de grano y forraje en híbridos de maíz y su generación avanzada F2. Agricultura Técnica en México, 35, 295-304.

[3] Betanzos Mendoza, E., Ramírez Fonseca, A., Coutiño Estrada, B., Espinosa Paz, N., Sierra Macias, M., Zambada Martínez, A. and Grajales Solis, M. (2009) Híbridos de maíz resistentes a pudrición de mazorca en Chiapas y Veracruz, México. Agricultura Técnica en México, 35, 391-400.

[4] Buccio, V.C.M., Martinez, J.O.A. and Morales, G.R.H. (2003) Contaminación con Hongos en Maíz Recién Cosechado en el Estado de Guanajuato durante el año 2003. Instituto de Ciencias Agrícolas de la Universidad de Guanajuato. Unidad de Estudios Superiores de Salvatierra de la Universidad de Guanajuato.

[5] Molina, G.D., Cortez, R.M.O., Burgos, H.A., Rosas, B.E.C. and Sánchez, M.R.I. (2004) Micoflora y presencia de fumonisinas en maíz de reciente cosecha en Sonora. Revista Salud pública y nutrición, edición especial, V Congreso Regional en Ciencias de los Alimentos, 2003, Monterrey, Nuevo León, núm. 1-2004, Universidad de Sonora, México.

[6] Braide, W., Oranusi, S.U., Udegbunam, L.I., Oguoma, O.I., Akobondu, C. and Nwaoguikpe, R.N. (2011) Microbiological Quality of an Edible Caterpillar of an Emperor Moth, Bunaea alcinoe. Journal of Ecology and the Natural Environment, 3, 176-180.

[7] Pereira, E.D.S., Sarquis, M.I.D.M., Ferreira-Keppler, R.L., Hamada, N. and Alencar, Y.B. (2009) Filamentous Fungi Associated with Mosquito Larvae (Diptera: Culicidae) in Municipalities of the Brazilian Amazon. Neotropical Entomology, 38, 352-359. http://dx.doi.org/10.1590/S1519-566X2009000300009

[8] Terenti, O. (2004) Calidad de la semilla, lo que implica y cómo evaluarla, ITA-San Luis. http://www.producción-animal.com.ar.

[9] Askun, T. (2006) Investigation of Fungal Species Diversity of Maize Kernels. Journal of Biological Sciences, 6, 275281. http://dx.doi.org/10.3923/jbs.2006.275.281

[10] Rooney, L.W. and Suhendro, E.L. (2001) Food Quality of Corn. In: Lusas, E.W. and Rooney, L.W., Eds., Snack Foods Processing, Technomic Publishing Co., Inc., Lancaster, 39-71. http://dx.doi.org/10.1201/9781420012545.sec2

[11] Raper, K.B. and Fennell, D.I. (1965) The Genus Aspergillus.

[12] Duarte-Vogel, S. and Villamil-Jiménez, L.C. (2006) Micotoxinas en la salud pública. Revista de Salud Pública, 8, 129-135. http://dx.doi.org/10.1590/S0124-00642006000400011

[13] Soriano, J.M. and Dragacci, S. (2004) Intake, Decontamination and Legislation of Fumonisins in Foods. Food Research International, 37, 367-374. http://dx.doi.org/10.1016/j.foodres.2004.01.008

[14] Naccha, L., Cavazos, N., Torres, A., Castillo, M. and Robledo, A. (2005) Ocratoxinas y su impacto en salud. CienciaUANL, 8, 373-378.

[15] Gallardo, R.E.D., Ibarra, M.G.M., Sánchez, M.R.I., Cuamea, C.G., Molina, G.D., Parra, V.N.V., Rosas, B.E.C. and Cortez, R.M.O. (2006) Micobiota de maíz (Zea mays L.) recién cosechado y producción de fumonisina B1 por cepas de Fusarium verticillioides (Sacc.) Nirenb. Revista Mexicana de Fitopatología, 24, 27-34.

[16] Pavón, M.Á., Luna, A., de la Cruz, S., González, I., Martín, R. and García, T. (2012) PCR-Based Assay for the Detection of Alternaria Species and Correlation with HPLC Determination of Altenuene, Alternariol and Alternariol Monomethyl ether Production in Tomato Products. Food Control, 25, 45-52.

http://dx.doi.org/10.1016/j.foodcont.2011.10.009

[17] Shephard, G.S., Berthiller, F., Burdaspal, P.A., Crews, C., Jonker, M.A., Krska, R., Sabino, M., et al. (2012) Devel- 
opments in Mycotoxin Analysis: An Update for 2011-2012. World Mycotoxin Journal, 6, 3-30. http://dx.doi.org/10.3920/WMJ2012.1492

[18] AAAC (Association of Chemical Analyst Cereals) (2001) American Association of Cereal Chemists. Approved Method 44-40, AACC, St. Paul, 1200 p.

[19] Sampson, R.A. and Pitt, J.I. (Eds.) (2000) Integration of Modern Taxonomic Methods for Penicillium and Aspergillus Classification. CRC Press, Boca Raton.

[20] Corral, J.A.R., García, G.M., Díaz, J.L.R., López, H.E.F., Ojeda, G.R., Olmos, J.D.M., de la Mora Orozco, C., et al. (2015) Cambio climático y sus implicaciones en cinco zonas productoras de maíz en México. Revista Mexicana de Ciencias Agrícolas, 1, 309-323.

[21] Chavarria, M., Rojas, V., Rumbos, N. and Narcise, R. (2014) Detección de microorganismos en maíz tierno molido comercializado en Maracay, estado Aragua, Venezuela. Revista de la Sociedad Venezolana de Microbiología, 34, 3337.

[22] NMX-FF-034/2-SCFI-2003. Productos alimenticios no industrializados para uso Humano-cereales. Especificaciones y métodos de prueba, Secretaría de Agricultura, Ganadería, Desarrollo Rural, Pesca y Alimentación, Dirección General de Normas, México.

[23] Johnson, M., Olaleye, O.N. and Kolawole, O.S. (2016) Antimicrobial and Antioxidant Properties of Aqueous Garlic (Allium sativum) Extract against Staphylococcus aureus and Pseudomonas aeruginosa. British Microbiology Research Journal, 14, 1-11. http://dx.doi.org/10.9734/BMRJ/2016/24095

\section{Submit or recommend next manuscript to SCIRP and we will provide best service for you:}

Accepting pre-submission inquiries through Email, Facebook, LinkedIn, Twitter, etc. A wide selection of journals (inclusive of 9 subjects, more than 200 journals)

Providing 24-hour high-quality service

User-friendly online submission system

Fair and swift peer-review system

Efficient typesetting and proofreading procedure

Display of the result of downloads and visits, as well as the number of cited articles

Maximum dissemination of your research work

Submit your manuscript at: http://papersubmission.scirp.org/ 